\title{
Identification of IL-1 $\beta$-induced messenger RNAs in rat pancreatic beta cells by differential display of messenger RNA
}

\author{
M.-C.Chen, F. Schuit, D. L. Eizirik \\ Diabetes Research Centre, Vrije University Brussel, Brussels, Belgium
}

\section{Abstract}

Aims/hypothesis. Interleukin- $1 \beta$ is a putative mediator of pancreatic beta-cell dysfunction and damage in Type I (insulin-dependent) diabetes mellitus. To better understand the molecular mechanisms involved in IL- $1 \beta$ effects, we carried out a differential display of mRNA by RT-PCR to identify novel cytokine-regulated genes.

Methods. Fluorescence activated cell sorting-purified rat pancreatic beta-cells were exposed for 6 or $24 \mathrm{~h}$ to IL-1 $\beta$. Differentially expressed cDNA bands were cloned and then identified by comparing their sequences with data from the GenBank. Differential gene expression was confirmed by RT-PCR using specific primers.

Results. Interleukin- $1 \beta$ increased the expression of adenine nucleotide translocator- 1 , phospholipase D1 and cytokine-induced neutrophil chemoattractant1 and decreased expression of the protein tyrosine phosphatase-like protein IA-2. Interleukin-1 $\beta$-in- duced differential expression of these genes in beta cells was confirmed by RT-PCR. In additional studies, IL- $1 \beta$ was shown to induce chemokines other than cytokine-induced neutrophil chemoattractant1 , including cytokine-induced neutrophil chemoattractant -3 and monocyte chemotactic protein-1.

Conclusion/interpretation. Our observations indicate that IL- $1 \beta$ modifies the expression of several genes in pancreatic beta cells. These genes may affect both function, viability and beta-cell recognition by the immune system. Functional characterization of the mRNAs which have been identified could facilitate a better understanding of the mechanisms leading to beta-cell destruction in Type I diabetes.

[Diabetologia (1999) 42: 1199-1203]

Keywords Beta cells, chemokine, phospholipase-D, DDRT-PCR, interleukin-1, monocyte chemoattractant protein-1, adenine nucleotide translocator, CINC-1, CINC-3.
Type I (insulin-dependent) diabetes mellitus is an autoimmune disease, where T-cells and macrophages invade the islets of Langerhans and lead to specific

Received: 4 June 1999 and in revised form: 1 July 1999

Corresponding author: D. L. Eizirik, Diabetes Research Centre, Vrije Universiteit Brussel, Laarbeeklaan 103, B-1090, Brussels, Belgium

Abbreviations: ANT, Adenine nucleotide translocator; CINC, cytokine-induced neutrophil chemoattractant; DDRT-PCR, differential display by reverse transcription-polymerase chain reaction; MCP-1, monocyte chemoattractant protein-1; OD, optical density; PLD-1, phospholipase D-1. destruction of pancreatic beta cells $[1,2]$. Cytokines such as interleukin- $1 \beta$ (IL- $1 \beta$ ) and interferon- $\gamma$ are released by these infiltrating mononuclear cells and can contribute to beta-cell death $[2,3]$. Recent observations indicate that genes and proteins activated by the beta cells are crucial to determine whether these cells will survive or undergo apoptosis when faced with immune-mediated cell damage [4-6].

We and others have previously adopted the "candidate gene" approach to characterize beta-cell responses to immune-mediated assaults and observed that cytokines induce the expression of different genes in rodent and human pancreatic islets, encoding both proteins involved in beta-cell damage and 
defence or repair or both [4, 7]. Unfortunately, the "candidate gene" approach allows only screening for known and individual genes. To overcome this limitation, in this study we used differential display of messenger RNA with the polymerase chain reaction (DDRT-PCR) [8, 9] to identify novel cytokine-induced genes of potential relevance for beta-cell damage, defence or repair, and apoptosis. For this purpose, DDRT-PCR was done on FACS-purified adult beta cells exposed for 6 or 24 h to IL- $1 \beta$ or control conditions (no cytokine added). These times were selected to detect both early and late responses to IL- $1 \beta$ [4] and the use of FACS-purified beta cells [10], instead of whole islets, increased the chance of identifying cytokine-induced, beta-cell genes.

We identified seven mRNAs whose expression is modified by IL- $1 \beta$ in rat beta cells. These genes could be involved in beta-cell damage and repair and in the process of mononuclear cell homing to the islets during insulitis.

\section{Materials and Methods}

Pancreatic islets were isolated from 10-week-old male Wistar rats by collagenase digestion and islet beta cells were purified by autofluorescence-activated cell sorting (FACStar, Beckton-Dickinson, Sunnyvale, Calif., USA) [10], and pre-cultured overnight at $37^{\circ} \mathrm{C}$ in Ham's F-10 medium (Gibco Brl-Life Technologies, Scotland) supplemented with $5 \mathrm{mg} / \mathrm{ml}$ charcoaltreated BSA (fraction V, RIA grade, Sigma, St. Louis, Mo., USA), $0.1 \mathrm{mg} / \mathrm{ml}$ streptomycin, $12.5 \mathrm{U} / \mathrm{ml}$ penicillin, $0.3 \mathrm{mg}$ / $\mathrm{ml} \mathrm{L}$-glutamine and $10 \mathrm{mmol} / \mathrm{l}$ glucose. This was followed by culture at $37^{\circ} \mathrm{C}$ in Ham's F-10 medium (Gibco) supplemented with $10 \mathrm{mmol} / \mathrm{l}$ glucose, $5 \mathrm{mg} / \mathrm{ml} \mathrm{BSA}, 0.1 \mathrm{mg} / \mathrm{ml}$ streptomycin, $12.5 \mathrm{U} / \mathrm{ml}$ penicillin, $0.3 \mathrm{mg} / \mathrm{ml} \mathrm{L}$-glutamine and $50 \mu \mathrm{mol} / 13$ isobutyl-l-methylxanthine (IBMX; Jansen Chimica, Beerse, Belgium) [11]. For DDRT-PCR $10^{6}$ beta cells were treated with $30 \mathrm{U} / \mathrm{ml}$ recombinant human IL- $1 \beta$ (kindly provided by Dr. C. W. Reynolds, National Cancer Institute, USA) for 6 or $24 \mathrm{~h}$ before mRNA isolation. $\operatorname{Poly}(\mathrm{A})^{+}$RNA was isolated from cell aggregates using oligo(dT $)_{25}$-coated polystyrene Dynabeads (Dynal, Oslo, Norway). The DDRT-PCR procedure was adapted from the original protocol [8], using the primer combinations described previously [9]. The protocol used for DDRT-PCR was described in detail in a previous publication, where we reported the induction of serine protease inhibitor-3 by IL- $1 \beta$ [12]. Differentially expressed cDNA bands detected by DDRT-PCR were reamplified and made visible on a $1.5 \%$ agarose gel to verify size and then cloned into the pCR 2.1 vector using the TA cloning system (Invitrogen, San Diego, Calif., USA). Clones of interest were further analysed by automated DNA sequencing (ABI Prism 310 Genetic Analyzer) using M13 primer and the Dye Terminator Cycle Sequencing kit (Perkin Elmer, Vaterstetten, Germany). The cDNA sequences were compared with those contained in the GenBank and EMBL database using GCG sequencing analysis software (Genetics Computer Group, Madison, Wis.,USA). For RT-PCR, rat beta cells $\left(10^{5}\right.$ cells $)$ were exposed for either 6 or $24 \mathrm{~h}$ to IL- $1 \beta(30 \mathrm{U} / \mathrm{ml})$. The insulinoma cell line RINm5F (provided by $\AA$. Lernmark, then at the Hagerdon Institute, Copenhagen, Denmark) was cultured at $5 \times 10^{4}$ cells/well in medium RPMI-1640 supplemented with $10 \%$ (vol/vol) fetal calf serum (FCS), $0.1 \mathrm{mg} / \mathrm{ml}$ streptomycin and $12.5 \mathrm{U} / \mathrm{ml}$ penicillin.

Reverse transcription-polymerase chain reaction. Gene specific primers and RT-PCR were used to confirm the differential expression of the genes detected during DDRT-PCR. Samples of cDNA (equivalent to 1500 cells) were amplified by PCR using AmpliTaq Gold DNA polymerase (Perkin Elmer). Polymerase chain reactions included $12 \mathrm{~min}$ predenaturation (hot start PCR) at $95^{\circ} \mathrm{C}$ and then cycles of: $94^{\circ} \mathrm{C}$ for $45 \mathrm{~s}, 58^{\circ} \mathrm{C}$ for $45 \mathrm{~s}$ and $72^{\circ} \mathrm{C}$ for $80 \mathrm{~s}$. Polymerase chain reaction cycles were 25 for islet antigen (IA)-2; 27 for adenine nucleotide translocator $(A N T)-1 ; 28$ for $G A P D H$ and $I A-2 \beta ; 29$ for inducible nitric oxide synthase $(i N O S), 30$ for cytokine-induced neutrophil chemoattractant (CINC)-1, (CINC)-3 and monocyte chemoattractant proteinn $(M C P)-1 ; 31$ for phospholipase D (PLD)-1. The cycles were selected to allow amplification within the linear range. The gene specific primer sequences and their respective PCR fragment lengths are ANT-1: 5'-GCCAGCAAACAGATCAGTGC-3', 5'-TGGGCAATCATCCAGCTCAC-3', (533 bp); CINC-1: 5'-ACAGTGGCAGGGATTCACTT-3', 5'-CTAGCACAGTGGTTGACACT-3', (468 bp); CINC-3: 5'-CAAGAACATCCAGAGCTTGA-3', 5'-TCAGACAGCGAGGCACATCA-3', (274 bp); GAPDH: 5'TCCCTCAAGATTGTCAGCAA-3', 5'-AGATCCACAACGGATACATT-3', (308 bp); IA-2: 5'-ATGGAGTAGAGCTGCGTCAG-3', 5'-CCCACCACACTGATGTTGAT-3', (502 bp); IA-2 $\beta$ : 5'-GGTACAGGTTTCACGTGGCA-3', 5'GCTGAGCTCATCTGGCTGGA-3', (411 bp); iNOS: 5'GACTGCACAGAATGTTCCAG-3', 5'-TGGCCAGATGTTCCTCTATT-3', (308 bp); MCP-1: 5'-ACCTGCTGCTACTCATTCAC-3', 5'-CTACAGAAGTGCTTGAGGTG3', (325 bp); PLD-1: 5'-TCCATCCGTAGTGTGCAGAC-3', 5'-GCAGCAGATCGGAGCAACTG-3', (371 bp). The identity of PCR fragments of each gene were confirmed by DNA sequencing (data not shown). The ethidium bromide-stained agarose gels were photographed under UV-transillumination using a Kodak Digital Science DC40 camera (Kodak, Rochester, N. Y., USA). Abundance of the PCR products of interest was assessed by Biomax 1D Image analysis software (Kodak) and expressed in pixel intensities [optical density (OD)], normalized for the abundance of the GAPDH signal amplified from the same cDNA sample. We have previously shown that IL-1 $\beta$ does not modify expression of the "housekeeping" gene GAPDH [13].

Statistical analysis. Values are expressed as means \pm SEM and comparisons were done by Student's paired $t$ test. A $p$ value of less than 0.05 was considered to be significant.

\section{Results}

With the use of DDRT-PCR we identified several fragments whose expression was changed by IL-1. Of them five had a high homology ( $>95 \%$ ) to published rat gene sequences, namely $A N T-1, I A-2$, $P L D-1$, and $C I N C-1$ (Table 1). The fifth gene, encoding for the putative cell defence protein serine protease inhibitor-3 (SPI-3), was described in a separate publication [12].

Using gene specific primers and RT-PCR we confirmed that the genes described in Table 1 are differentially regulated by IL- 1 in rat beta cells (Fig. 1 and 
Table 1. cDNA clones isolated by DDRT-PCR

\begin{tabular}{lllcl}
\hline clone & gene & GenBank & matched region & homology \\
\hline DD134 & $A N T-1$ & X61667 & $4710-4820$ & $97 \%$ \\
DD165 & $I A-2$ & D45414 & $1540-1900$ & $97 \%$ \\
DD175 & $P L D-1$ & AB000779 & $2300-2700$ & $98 \%$ \\
DD185 & CINC-1 & D11444 & $230-700$ & $98 \%$
\end{tabular}

DDRT-PCR was done on beta cells exposed for 6 or $24 \mathrm{~h}$ to IL$1 \beta$ or control condition. cDNA bands detected by DDRT-PCR were cloned into the pCR2.1 vector and analysed by automated DNA sequencing. The cDNA sequences obtained were compared with those available in the GenBank. A fifth clone isolated by DDRT-PCR, DD10, represents the gene encoding for serine protease inhibitor-3 [12]

Table 2. Effects of 6 -h and $24-\mathrm{h}$ exposure to IL- $1 \beta$ on beta cell mRNA expression

\begin{tabular}{llllll}
\hline & 6-h & & & & $24-\mathrm{h}$ \\
\cline { 2 - 3 } \cline { 5 - 6 } & Control & IL-1 $\beta$ & & Control & IL-1 $\beta$ \\
\hline ANT-1 & $0.39 \pm 0.10$ & $0.80 \pm 0.20^{\mathrm{a}}$ & & $0.55 \pm 0.13$ & $0.84 \pm 0.15^{\mathrm{b}}$ \\
IA-2 & $0.37 \pm 0.07$ & $0.38 \pm 0.10$ & & $0.79 \pm 0.17$ & $0.43 \pm 0.12^{\mathrm{b}}$ \\
IA-2 $\beta$ & $0.95 \pm 0.06$ & $0.82 \pm 0.06$ & & $1.17 \pm 0.21$ & $0.75 \pm 0.16^{\mathrm{a}}$ \\
PLD-1 & $0.35 \pm 0.08$ & $0.81 \pm 0.08^{\mathrm{b}}$ & & $0.63 \pm 0.08$ & $0.62 \pm 0.14$ \\
CINC-1 & BD & $1.24 \pm 0.14$ & & BD & $0.62 \pm 0.05$ \\
CINC-3 & BD & $0.73 \pm 0.08$ & & BD & $0.31 \pm 0.05$ \\
MCP-1 & BD & $0.94 \pm 0.13$ & & BD & $0.45 \pm 0.13$ \\
iNOS & BD & $0.98 \pm 0.13$ & BD & $0.55 \pm 0.17$ \\
\hline
\end{tabular}

Beta cells were exposed for 6 or $24 \mathrm{~h}$ to IL-1 $\beta(30 \mathrm{U} / \mathrm{ml})$ and the cells then retrived for poly $(\mathrm{A})^{+}$mRNA extraction and RT-PCR. PCR band intensities were expressed as OD and corrected for GAPDH expression. The results obtained are means \pm SEM for 3-6 experiments. ${ }^{\mathrm{a}} p<0.05,{ }^{\mathrm{b}} p<0.01$ vs corresponding control groups. $\mathrm{BD}$, below detection limit. No statistical analysis was done when control values were below detection limit

Table 2). The expected PCR fragment lengths were detected and DNA sequencing of the PCR products confirmed the identity of the genes (data not shown). The activity of IL- 1 was confirmed by its induction of iNOS gene expression in beta cells (Fig.1), a well characterized effect of the cytokine in insulin-producing cells [4]. As previously described [14], IL-1 $\beta$ induced a high $i$ NOS expression after $6 \mathrm{~h}$, with subsequent decline after a 24-h exposure to the cytokine (Table 2).

Interleukin- $1 \beta$ increased the expression of the nuclear DNA-encoded ANT-1 mRNA by twofold after $6 \mathrm{~h}$, and this increased expression was maintained after a 24-h exposure to the cytokine (Fig.1, Table 2). The mRNAS encoding for the tyrosine phosphataselike proteins IA- 2 and IA- $2 \beta$ were expressed in beta cells under basal conditions, and this expression was not modified by a $6 \mathrm{~h}$ exposure to IL-1 $\beta$ (Fig. 1 ; Table 2). A more prolonged treatment with the cytokine $(24 \mathrm{~h})$, lead, however, to a statistically significant decrease in IA-2 and IA- $2 \beta$ expression (Table 2 ).
$6 \mathrm{~h} \quad 24 \mathrm{~h}$
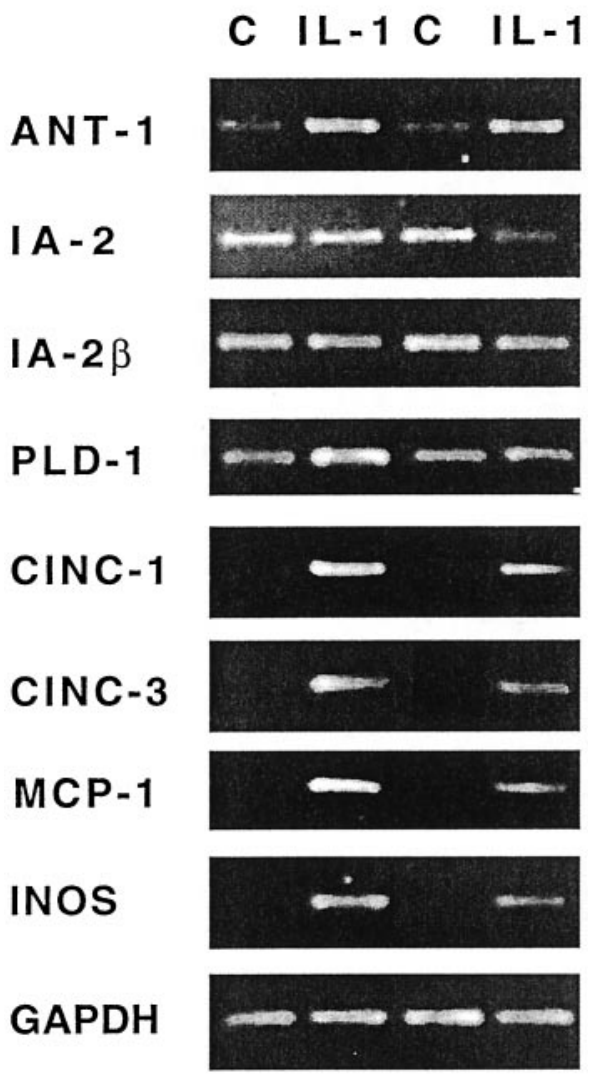

Fig. 1. Interleukin- $1 \beta$-induced gene expression in rat beta cells. Rat beta cells $\left(5 \times 10^{4}\right.$ cells/well $)$ were exposed to IL- $1 \beta$ $(30 \mathrm{U} / \mathrm{ml})$ or control condition $(\mathrm{C}$; no cytokine added) for 6 or $24 \mathrm{~h}$. After these times the cells were harvested, mRNA extracted and RT-PCR done with the equivalent of $3 \times 10^{3}$ cells. The pictures shown are representative for 3-6 similar experiments. Quantification of these results as OD are shown in Table 2

Phospholipase D-1 mRNA expression increased by twofold after a 6 -h exposure to IL-1 $\beta$ (Table 2). After a 24 -h culture in the presence of IL- $1 \beta$ PLD-1 mRNA expression returned to basal levels (Table 2).

Expression of the mRNA encoding for the chemokine CINC-1 was undetectable in control beta cells but it was induced by IL-1 after $6 \mathrm{~h}$, with a slight decline after $24 \mathrm{~h}$ (Fig. 1 and Table 2). To analyse whether IL-1 $\beta$ induces chemokines other than CINC-1, we examined CINC-3 and MCP-1 expression. There was a similar pattern as observed for CINC-1, namely the cytokine induced a clear expression of the mRNAs encoding for CINC-3 and MCP-1 after both 6 and $24 \mathrm{~h}$ of exposure. To exclude that IL$1 \beta$-induced chemokine mRNA expression was due to the small contamination of non-beta cells $(<10 \%)$ present in our beta-cell preparations, these experiments were reproduced using the clonal rat insulinproducing cell line RINm5F. W observed, smilarly to the data on beta cells, undetectable basal CINC-1, 
CINC-3 and MCP-1 mRNA expression, followed by a clear IL- $1 \beta$-induced mRNA expression after $6 \mathrm{~h}$ (data not shown).

\section{Discussion}

Since its original development [8], DDRT-PCR has been widely used to detect changes of gene expression in eukaryotic cells exposed to different stimuli. We have used this technique to detect IL- $1 \beta$-induced genes in rat pancreatic beta cells. Based on the DDRT-PCR, and on additional experiments to complement the differential display, we detected seven IL- $1 \beta$-induced genes in rat pancreatic beta cells. These genes include the adenine translocator gene ANT-1; chemokines CINC-1, CINC-3 and MCP-1; and three genes potentially involved in beta-cell signal transduction, namely $P L D-1, I A-2$ and $I A-2 \beta$. It is noteworthy that we did not detect by the DDRTPCR some well-known, cytokine-induced genes, such as $i N O S$ and Mn superoxide dismutase [4]. This suggests that the present method, although useful to identify some cytokine-affected genes, does not guarantee the identification of all mRNAs whose expression is modified by IL- $1 \beta$.

The three isoforms of ANT (1-3) are nuclear DNA-encoded mitochondrial proteins which control the ATP supply of the cell by regulating the exchange of ADP and ATP across the mitochondrial internal membrane [15]. Adenine nucleotide translocator- 1 is expressed in heart and skeletal muscle [16] and in beta cells ([17], present data). We observed that ANT-1 expression in beta cells is enhanced by IL-1 $\beta$ both after 6 and $24 \mathrm{~h}$ of exposure. It has been previously shown that ANT-1 mRNA expression decreases after inhibition of beta-cell function by streptozotocin or culture at low glucose concentrations [17]. Exposure of FACS-purified beta cells for $20 \mathrm{~h}$ to IL$1 \beta$, under experimental conditions similar to the present study, leads to severe inhibition of beta-cell function [18], which is accompanied by an increased ANT-1 mRNA expression (present data). This indicates that ANT-1 expression and beta-cell function can be dissociated.

Chemokines are small molecules secreted by a variety of cell types, which play an important part in the recruitment and activation of immune cells [19]. Monocyte chemoattractant protein- 1 is a CC chemokine, attracting mostly monocytes and T lymphocytes [20]. Cytokine-induced neutrophil chemoacttractant proteins are the rat counterpart of human growth-regulated gene products [21] and belong to the CXC group of chemokines. The expression of the chemokines CINC and MCP-1 can be induced by pro-inflammatory cytokines $[19,20]$ and these cytokines are probably secreted in the vicinity of the beta cells during insulitis $[2,3]$. We observed that IL- $1 \beta$ induces the expression of three chemokines in beta cells, MCP-1, CINC-1 and CINC-3. Monocyte chemoattractant protein-1 - a chemoattractant for mononuclear cells - is probably the most relevant in the context of insulitis. It has been previously shown that transgenic expression of MCP-1 in pancreatic islets induces a monocyte-rich insulitis without diabetes [22]. This, taken together with the present data, raises the possibility that beta-cell exposure to IL- $1 \beta$ during early insulitis leads to MCP1 production, further potentiating immunocyte infiltration and beta-cell damage.

Phospholipase- 1 catalyses the hydrolysis of phosphatidylcholine to form phophatidic acid and choline, which play an important part in signal transduction, cell growth and the intracellular protein trafficking and secretion [23]. Phophatidic acid generated by PLD can be further converted to diacylglycerol which has been described as being increased by in beta cells IL-1 $\beta$ [24]. Interleukin- $1 \beta$-induced diacylglcycerol production leads to protein kinase $\mathrm{C}$ activation and stimulation of insulin release [24]. Thus, it is conceivable that the early and transitory induction of PLD-1 by IL- $1 \beta$ observed contributes to the previously described early and transitory stimulatory effects of IL$1 \beta$ on insulin release [24]. In line with this possibility, exogenous phosphatidic acid or PLD stimulates insulin release by rat pancreatic islets [25].

Islet antigen- 2 and IA- $2 \beta$ are protein tyrosine phosphatase-like proteins and are known as major islet cell autoantigens in Type I diabetes [26]. The functional role for this protein in beta cells is still to be clarified. Circulating autoantibodies against IA 2 or another beta-cell autoantigen, the enzyme glutamate decarboxylase, are detected in the sera of up to $80 \%$ of patients at the clinical onset of the disease and in sera of pre-diabetic people [27]. We observed that prolonged (24-h) exposure of beta cells to IL- $1 \beta$ inhibits IA- 2 and IA- $2 \beta$ mRNA expression. Note that IL- $1 \beta$ also inhibits the expression of the beta-cell autoantigen glutamate decarboxylase [28].

Our study identified seven mRNAs whose expression is modified by IL- $1 \beta$ in rat beta cells. Clarification of the functional role of these genes for in vitro beta-cell damage and repair, and for the in vivo progression of insulitis in animal models of diabetes mellitus, will hopefully broaden our understanding of the pathogenesis of Type I diabetes.

Acknowledgements. We are grateful to Professor D. G. Pipeleers for providing access to FACS-sorted beta-cells, to E. Quartier for DNA sequencing and to R. Leeman, E. Verheugen and the personnel involved in rat islet isolation and betacell FACS sorting for technical assistance. This work was supported by grants from the Juvenile Diabetes Foundation International (JDFI - 1982029), the Research Programme of the Fund for Scientific Research - Flanders (FWO G.0216.99 and FWO Research Prize Pharmacia \& Upjohn) and by a Shared Cost Action in Medical and Health Research of the European Community (BMHY-CT98-3448). 


\section{References}

1. Bach JF (1995) Insulin-dependent diabetes mellitus as a beta-cell targeted disease of immunoregulation. J Autoimmun 8: 439-463

2. Mandrup-Poulsen T (1996) The role of interleukin-1 in the pathogenesis of IDDM Diabetologia 39: 1005-1029

3. Rabinovitch A, Suarez-Pinzon WL (1998) Cytokines and their roles in pancreatic islet $\beta$-cell destruction and insulindependent diabetes mellitus. Biochem Pharmacol 55: 1139-1149

4. Eizirik DL, Flodström M, Karlsen AE, Welsh N (1996) The harmony of the spheres:inducible nitric oxide synthase and related genes in pancreatic beta cells. Diabetologia 39: 875-890

5. Mauricio D, Mandrup-Poulsen T (1998) Apoptosis and the pathogenesis of IDDM:a question of life and death. Diabetes 47: $1537-1543$

6. Eizirik DL, Hoorens A (1999) B-cell dysfunction and death. In: Howell SL (ed) Biology of the Pancreatic BCell. Series Advances in Molecular and Cell Biology 29. JAI Press, Connecticut, USA, pp 47-73

7. Eizirik DL, Pavlovic D (1997) Is there a role for nitric oxide in $\beta$-cell dysfunction and damage in IDDM? Diabetes/ Metab Rev 13: 293-308

8. Liang P, Pardee AB (1992) Differential display of eukaryotic messenger RNA by means of the polymerase chain reaction. Science 274: 787-789

9. Bauer D, Müller K, Reich J et al. (1993) Identification of differentially expressed mRNA species by an improved display technique (DDRT-PCR). Nucleic Acids Res 21: 4272-4280

10. Pipeleers DG, In't Veld PA, Van De Winkel M, Maes E, Schuit FC, Gepts W (1985) A new in vitro model for the study of pancreatic A and B cells. Endocrinology 117: 806-816

11. Ling Z, Hannaert JC, Pipeleers D (1994) Effect of nutrients, hormones and serum on survival of rat islet $\beta$ cells in culture. Diabetologia 37: 15-12

12. Chen MC, Schuit F, Pipeleers DG, Eizirik DL (1999) IL-1 $\beta$ induces serine protease inhibitor 3 (SPI-3) gene expression in rat pancreatic $\beta$-cells. Detection by differential display of messenger RNA. Cytokine (in press)

13. Eizirik DL, Björklund A, Cagliero E (1993) Genotoxic agents increase expression of growth arrest and DNA damage-inducible genes gadd 153 and gadd 45 in rat pancreatic islets. Diabetes 42: 738-745

14. Niemann A, Björklund A, Eizirik DL (1994) Studies on the molecular regulation of the inducible form of nitric oxide synthase (iNOS) in insulin-producing cells. Mol Cell Endocrinol 106: 151-155
15. Klingenberg M (1992) Structure-function of the ADP/ATP carrier. Biochem Soc Trans 20: 547-550

16. Li K, Warner CK, Hodge JA et al. (1989) A human muscle adenine nucleotide translocator gene has four exons, is located on chromosome 4, and is differentially expressed. J Biol Chem 264: 13998-14004

17. Welsh N, Svensson C, Welsh M (1989) Content of adenine nucleotide translocator mRNA in insulin-producing cells of different functional states. Diabetes 38: 1377-1380

18. Ling Z, Chen MC, Smismans A et al. (1998) Intercellular differences in interleukin $1 \beta$-induced suppression of insulin synthesis and stimulation of noninsulin protein synthesis by rat pancreatic $\beta$-cells. Endocrinology 139: 1540-1545

19. Baggiolini M, Dewald B, Moser B (1997) Human chemokines:an update. Annu Rev Immunol 15: 675-705

20. Rollins BJ (1996) Monocyte chemoattractant protein 1:a potential regulator of monocyte recruitment in inflammatory disease. Mol Med Today 2: 198-204

21. Nakagawa H, Komorita N, Shibata F et al. (1994) Identification of cytokine-induced neutrophil chemoattractants (CINC), rat GRO/CINC-2 $\alpha$ and CINC- $2 \beta$, produced by granulation tissue in culture:purification, complete amino acid sequences and characterization. Biochem J 301: 545-550

22. Grewal IS, Rutledge BJ, Fiorillo JA et al (1997) Transgenic monocyte chemoattractant protein-1 (MCP-1) in pancreatic islets produces monocyte-rich insulitis without diabetes. J Immunol 159: 401-408

23. Gomez-Cambronero J, Keire P (1998) Phospholipase D:a novel major player in signal transduction. Cell Signal 10: 387-397

24. Eizirik DL, Sandler S, Welsh N, Juntti-Berggren L, Berggren P-O (1995) Interleukin- $\beta$-induced stimulation of insulin release in mouse pancreatic islets is related to diacylglyerol production and protein kinase $\mathrm{C}$ activation. Mol Cell Endocrinol 111: 159-165

25. Metz SA and Dunlop M (1990) Stimulation of insulin release by phospholipase D - a potential role for endogenous phosphatidic acid in pancreatic islet function. Biochem $\mathbf{J}$ 270: 427-435

26. Passini N, Larigan JD, Genovese S, Appella E, Sinigaglia F (1995) The 37/40-kilodalton autoantigen in insulin-dependent diabetes mellitus is the putative tyrosine phosphatase IA-2. Proc Natl Acad Sci USA 92: 9412-9416

27. Lan MS, Wasserfall C, Maclaren NK, Notkins AL (1996) IA2, a transmembrane protein of the protein tyrosine phosphatase family, is a major autoantigen in insulin-dependent diabetes mellitus. Proc Natl Acad Sci USA 93: 6367-6370

28. Velloso LA, Björk E, Ballagi AE et al. (1994) Regulation of GAD expresion in islets of Langerhans occurs both at the mRNA and protein level. Mol Cell Endocrinol 102: 31-37 